This is a preliminary draft version, please do not quote or circulate. Thank you.

\title{
Populism as Communication: Political Campaigning on Facebook
}

Karolina Koc-Michalska, Audencia Business School, Nantes, France, kkocmichalska@audencia.com Ulrike Klinger, European University Viadrina, Frankfurt, Germany, klinger@europa-uni.de

Abstract: In this article we adopt the notion of populism as a communication phenomenon that includes typical elements of content (i.e. people, anti-elitism, and the exclusion of out-groups) and of style (i.e. evoking fear, oversimplification, and style of language). We thus move away from actor-centered approaches towards a content-centered approach of studying populism. Empirically, our study measures populism to varying degrees and forms in 3564 Facebook postings of political parties in France, Germany and the United Kingdom during the 2014 EU elections campaigns, the 2017 national parliamentary election campaigns, and a non-electoral period in 2018 in each country. The results show that populism is not a marginal phenomenon, but that it is present in about one fourth of all postings in some form; that there is variance between countries, party types, policy fields, and over time. While radical parties are very exclusionary towards out-groups on the radical right and very anti-elitist on the radical left and the radical right, this observation provides only a partial view of the multifaceted phenomenon of populism.

Keywords: populism, elections, Europe, social media, quantitative content analysis

\section{Introduction: Populism as communication}

Populism is everywhere: it is evident in the news, in public discourses, and in political communication research. Over the past 30 years the support for populist radical right-wing parties rose to a historic high (Tartar 2017). Populism has become a ubiquitous research topic - not only due to the upsurge of right-wing and left-wing populist leaders, parties, and movements, but also because populism is a mesmerizing phenomenon. It is notoriously vague (Canovan 1999), promiscuous (Oliver \& Rahn 2016), chameleonic (Taggart 2000), and an opaque zeitgeist (Mudde 2004) at the conceptual level, and therefore poses an irresistible challenge to social scientists. 
Recently, de Vreese et al. (2018: 3) evoked the notion of "a new generation of populism researchers". In this section we argue that an understanding of populism as communication indeed enables researchers to bridge the current debates on whether or not populism is an ideology, a discourse, a mobilization strategy, an organizational type, or a political logic (Moffit \& Tormey 2015, Author2 2017, Zulianello et al. 2018).

In line with de Vreese et al. (2018) we view populism as a communication phenomenon that includes typical elements of content (i.e. people, anti-elitism, and the exclusion of out-groups) and of style (i.e. evoking fear, oversimplification, and style of language). In this reading populism is not about an actors' attributes, but about an actor's actions. Furthermore, we do not view populism in terms of an either/or, populist/non-populist dichotomy, but as a phenomenon that varies in degree.

In the decade since the publication of Mudde's (2004) influential work on populism as a thin or thin-centered ideology, a near consensus emerged among scholars about its ideational character (Hawkins 2012, Mazzoleni 2008, Pauwels 2011): Populism as a set of ideas that focuses on pure and good people versus corrupt and bad elites, understood to be two homogenous and antagonistic social entities. This antagonism is contextualized by other ideational elements such as the political supremacy of the will of the people, invocations of a heartland, and the exclusion of out-groups. Recent publications critiqued this ideational understanding of populism. Amongst others, Moffit and Tormey (2014) ask whether a "thin ideology can actually become so thin as to lose its conceptual validity and utility" (p. 383).

Whereas notions of populism as an ideology tend to underestimate the role of communication, the body of literature on populism as a discursive framework or a communication strategy is growing (e.g. Poblete 2015; Casero-Ripollés et al. 2017). As de Vreese et al. (2018) argue, "populist ideas must be communicated discursively to achieve the communicator's goals and intended effects on the audience." (p. 3). Conceptualizing populism as a political logic or a discourse is, however, not a new approach (Laclau 2005). In contrast to the popular discourse that merely accuses actors of being populist, "implying reckless and unscrupulous demagogy" (McGuigan 1992: 1), both populism as ideology and populism as discourse attempt to identify populists and are thus actor-centered. The objective of these two approaches is to determine who is a populist and how populists differ from other political actors.

The focus on populism as communication changes the research objective by analyzing who uses populist communication to what extent and through which channels with what effect. Therefore, populism becomes a matter of degree as we expect all political actors to use some 
populist communication (in terms of both content and style) to varying degrees in different situations. Here we adopt the approach of de Vreese et al. (2018) who conceptualize populism as a communication phenomenon and not as an ideology, a discourse, or a strategy that needs to be communicated. Accordingly:

"the emphasis is on populist messages as independent 'phenomenon-as-such' and no longer on a particular party family or type of politician. With populism 'as content' we refer to the public communication of core components of populist ideology (such as people-centrism and anti-elitism) with a characteristic set of key messages or frames. With populism 'as style', we refer to the fact that these messages expressing populist ideology are often associated with the use of a characteristic set of presentational style elements." (de Vreese et al. 2018: 3)

As indicated, populism refers to three core elements, namely the people, anti-elitism, and the exclusion of out-groups.

People: Essentially, populism appeals to the people - not for the sake of the people as such, but in opposition to the values and ideas of elites and certain minority groups who do not belong to "the people". As an element of populism, the people is a rhetorical construct that is instrumental and that can be exploited, and its meaning is not the same as the citizens or the population of a territory. As a united, homogenous group of ordinary people, the silent majority (Oliver \& Rahn 2016), the notion of the people is a fiction. In this view, the people are united, solidary, guided by common sense, endowed with the same interests, values and opinions, and can be invoked into many forms such as the nation, peasants, voters or the proletariat (Rooduijn 2014). In populism the people are in a default state of crisis, threatened by others from the outside, which is why populism has been associated with a Manichaean perspective and a dualist world view of Us versus Them.

Anti-elitism: Similar to the people, the elite refers to a homogenous group with its identity based on antagonism directed at the people (Engesser et al. 2017). Elites are found in the political, economic and legal systems, in the media, and in supranational institutions. The core idea behind anti-elitism is the attribution of blame. When conjuring up a people in crisis, elites are blamed as either unable or unwilling to represent the people's will and to respect the people's sovereignty. Populism's opposition to complexity is connected to anti-elitism: "complexity is a self-serving racket perpetuated by professional politicians," (Canovan 1999: 6) suggesting that policy should be guided by the people's common sense that is actually pure and simple. The degree of antagonism also varies: populism always presents itself as distinct 
from elites but, rather than blaming or shaming elites, it may oppose other groups in society as well (Moffit \& Tormey 2014).

Out-groups: Some scholars contend that the exclusion of out-groups is not a key feature and element of populism as such, but only one of radical right-wing populism. We argue, along with de Vreese et al. (2018), that the exclusion of out-groups is not a defining element of all variants of populism, but is one that features both on the right and the left of the populist spectrum. The exclusion of others constitutes the horizontal dimension of populism's inherently antagonistic character. Elites are those in power and therefore the enemy from above; out-groups - being groups that populists stigmatize as a threat or a burden to the people (Jagers \& Walgrave 2007) - are the enemy from within society. Once more, the out-group is a construction of "a blameless in-group opposed to a culprit out-group." (Hamleers et al. 2017: 872) In this sense, Rovira Kaltwasser (2018) differentiates between exclusionary and inclusionary populism. While the former is often rooted in notions of nativism and right-wing ideologies that oppose immigrants, ethnic and religious minorities, homosexuals or welfare recipients, the latter focuses on radical left-wing positions and constructs a homogenous group out of those affected by alleged unjust socioeconomic policies and austerity measures. Similarly, Hameleers \& Vliegenthart (2020) differentiate left- and right-wing exclusion. In our operationalization we do not make this differentiation of who is excluded, but focus on the question whether any groups are excluded (see codebook V8 ostracism).

Based on the contributions of Jagers and Walgrave (2007) and de Vreese et al. (2018), we apply a typology of populism that differentiates between four levels of populism as a communication phenomenon and that to varying degrees can be empirically identified in political messages.

$$
\begin{array}{ll}
\text { Full populism: } & \text { people }+ \text { elite }+ \text { out-group } \\
\text { Anti-elitist populism: } & \text { people }+ \text { elite } \\
\text { Exclusionary populism: } & \text { people }+ \text { out-group } \\
\text { Empty populism: } & \text { people }
\end{array}
$$

In this typology the invocation of the people is at the core of populism and produces different types of populism depending on whether or not it is linked to the elite and out-group elements. Full populism combines all three elements. Anti-elitism or the exclusion of out-groups individually do not constitute populism; both only do so in combination with the people element. Similarly, the mere invocation of the people without reference to anti-elitism or out- 
groups, is deemed to be empty populism, the thin, "empty-shell, initial definition" of populism (Jagers and Walgrave 2007: 323).

Although, regarding content, people, anti-elitism, and the exclusion of out-groups form three "pillars of populist discourse," (Bobba 2018: 2) we must also consider how populism manifests in the style of messages, that is how actors present ideas and information. As previously argued, populism is not about the attributes of a political actor, but about the actions of an actor. Populism is performed; it is what is said and how it is said (Bracciale and Martella 2017). Also, performing populism is not limited to the political right or left, since "politicians can slip in and out of the populist style.” (Moffit \& Tomey 2014: 393) The performative style of populism has been described as direct, emotional (Canovan 1999), simple (avoiding complexity) and blunt. The populist transgresses the limits of presumed political correctness: "like a 'drunken guest' (...) with 'bad manners' (...), the populist disrupts the normal dinner table, much to the discomfort, even alarm, of the usual patrons.” (Oliver \& Rahn 2016: 191) Populism is emotional and evokes emotions by purposefully breaching the taboos of mainstream politics and political culture, by employing calculated provocations (Pauwels 2011), and by taking on a narrative of underdogs (Mazzoleni 2008), of self-victimization, or other symbolic themes. These emotions emphasize fear and anger (Hameleers et al. 2017).

To address these issues and to conceptualize populism as a communication phenomenon, we study both populism in content $(\mathrm{PiC})$ and populism in style (PiS). Both aspects vary in degree, as actors from across the political spectrum can employ populist content and style elements in their public communication. As Stanyer et al (2016) point out, "it is important to reiterate that most studies are actor centered and that we lack systematic empirical studies. Consequently, our knowledge is poor about how frequently both populist and non-populist mainstream political actors refer to the people, express anti-elitism, and exclude various out-groups in their communication.” (p. 361)

\section{Populism in election campaigns}

As shown, recent empirical studies have begun to address populism as a communication phenomenon, also considering that the proliferation of social media platforms allows access to populist communication with an additional type of data. Whereas previous research was limited to highly formalized genres like public speeches and party manifestoes, social media enable scholars to monitor the use and effects of political communication in a more granular fashion. Social media have become standard platforms for election campaigns, where parties and politicians broadcast their messages unfiltered by journalists or other gatekeepers. Social media 
postings are less formalized than party platforms, the way content is produced, distributed and used is very different from traditional mass media (Klinger \& Svensson 2015). In the fourth era of campaigning (Römmele \& Gibson 2020), social media postings provide a numerous and fertile material to study the use of populist messages and populist elements in party communication.

Not surprisingly, populism has become a popular research topic of political communication scholars interested in the impact of social media platforms. Although the data is proprietary and only partially accessible through APIs, it has nonetheless brought about an increase in quantitative empirical research designs (Author2 2016; Bobba 2018; Ernst et al. 2017; Hameleers \& Schmuck 2017; Stier et al. 2017; Van Kessel \& Castelein 2016; Zulianello et al. 2018). This is all the more relevant as experiments show that populist elements have mobilizing and de-mobilizing effects on voters (Hameleers et al. 2018).

Social media offer a communication environment that significantly differs from traditional mass media outlets. The affordances of social media platforms provide a particularly fertile ground for populist communication, being mostly un-edited, enabling public communication outside of and circumventing journalistic outlets. On social media, political parties remain in control of their messages, they can tailor messages according to target groups or use microtargeting tools for political advertisements (Kreiss 2016). It is popularity and not news values or other professional criteria that determine the relevance and reach of a message. Indeed, there is empirical evidence that purported populist parties have profited from social media (Bobba 2018), that they find new supporters among adolescents (Heiss \& Matthes 2017), that populist messages receive more comments online and "prompt citizens to use populist messages themselves in their comments" (Blassnig et al 2019: 629).

However, previous studies have shown that social media platforms are by no means a "populist paradise," since populist parties often have a centralized structure and avoid internal dissent (Jacobs \& Spierings 2018). A study on Twitter use by populist presidents in Latin America found that the prevalent communication mode remains top-down (Waisbord \& Amado 2017), confirming that populist communication on social media tends towards normalization/politics as usual (Author2, 2014). In their social media practices, populist actors are not always and necessarily more apt to respond and engage with the people (Spierings et al. 2018).

While social media data call for comparative analyses, only few empirical studies have made comparisons across countries and even less so across time. Rooduijn (2014) set an example by using data obtained from newspaper articles, comparing five countries where, over two decades 
(1988-2008), populist parties (at the time) had varying success. Ernst et al. (2017) analyzed 1400 Twitter and Facebook postings from six countries, published by 88 politicians from 29 political parties. They found that parties at the fringes of the political spectrum and opposition parties were more prone to populist communication - a finding that should be tested in different situations (electoral and non-electoral periods $>\mathrm{H} 1$ ). In another study on politician statements from six Western democracies, Ernst, Esser \& Blassnig (2019) found that populist communication is associated with typical issues (such as immigration, crime and economic hardship), and that politicians from populist parties are more populist in their communication. They particularly stress the importance of studying content and style of populist messages, claiming that "the ideology of populism cannot be communicated without stylistic elements" (p. 167). Engesser et al.'s (2017) comparative qualitative text analysis showed that "populism manifests itself in a fragmented form on social media," (p. 1109) justifying the need for a differentiated and comparative look at party messages on Facebook or Twitter. Engesser, Fawzi and Larsson (2017) provided a useful operationalization, based on emotionalization and negativity (p. 1282), to identify variations in content and style. Even though the thresholds they apply are debatable, Zulianello, Albertini and Ceccobelli (2018) compared the Facebook communication of 83 political leaders from six Western and Latin American countries, showing that populism as communication can be empirically identified and that it varies extensively across parties and actors.

Our study seeks to determine if and how party characteristics influence the prevalence of populism in content $(\mathrm{PiC})$ and populism in style (PiS), and - based on the research presented above - to test the following hypotheses.

While many studies have already unsurprisingly confirmed that populist parties or populist politicians communicate in a more populist way regarding content and style (e.g. Wettstein et al 2019), we seek to focus on other party features such as party size, party position and political ideology. Based on the findings in Ernst et al (2017) and Koc-Michalska et al (2018) that showed how major fringe parties are more likely to use populist elements in a study across 117 parties in 14 EU countries, we hypothesize about party size (here understood as size in parliament) and populism:

H1: Party size impacts on populism: fringe parties have a higher PiC and PiS than major parties.

To our knowledge, there has been no comparison so far about populist communication of parties in government and opposition parties. Albertazzi and McDonnell (2015) have shown, however, 
that populists in Italy and Switzerland can in fact govern effectively and "without laying aside their radical rhetoric“" (p.170). In our country sample, no populist party has been in government position, all have remained opposition parties. Therefore, we expect here more populist communication among opposition parties.

H2: Party position impacts on the level of populism: opposition parties have a higher PiC and PiS than government parties.

Ernst et al (2017) concluded that populist communication is mostly used by parties at the extremes of the political spectrum, both left and right. Engesser et al (2017) showed that left parties tended towards attacking economic elites, whereas right-wingers attacked media elites and ostracized out-groups. Almost all populist parties in our country sample are right-wing. Based on this we expect to find more populism among right wing parties.

H3: Political ideology impacts on populism: right-wing parties have a higher PiC and PiS than left-wing parties.

By using a comparison across countries, election types and over time - comparing EU elections 2014, national parliamentary elections 2017 and a non-electoral period 2018 in France, Germany and the United Kingdom - we also want to determine if and how populism in content and populism in style changed over time. Previously, researchers have shown that the presence of populism and populist elements have been increasing over time in party manifestoes and traditional media (Hameleers \&Vliegenthart 2020; Manucci \& Weber 2017), and that populists have been increasingly successful in elections (Tartar 2017, Neuner \& Wratil 2017). Based on this we assume that:

H4: PiC and PiS increase over time.

While populism does not increase in a linear and simultaneous way, Manucci \& Weber (2017) show increases of populism in party manifestoes and newspapers across four countries after 2010, including Germany and the UK. With H5 and H6 we seek to test whether populism increases with time or in relation to election types:

H5: PiC and PiS increase in all three countries.

Second-order elections are characterized by lower turn-outs, better prospects for small and new parties, worse prospects for government parties, a tendency towards protest voting, and perceptions that less is at stake (Reif \& Schmitt 1980). Owing to these differences, campaigns 
and campaign strategies vary and we expect to detect different levels of populism in communication. In the 2014 EU election campaigns, public interest in candidates and election as well as voter turnout were at record low levels (Treib 2014). Based on this we expect more populist communication during national elections.

H6: PiC and PiS are more prevalent during first-order elections than during second-order elections and non-electoral periods.

To our knowledge, the only study so far connecting populism to specific topics or policy fields is Ernst, Esser \& Blassnig (2019), finding that there are indeed typical issues connected with populist communication. A possible reason for this research gap is that populism research either focused on right-wing or on left-wing parties, thus on ideologies rather than on policy fields. If we follow the notion of populism as communication, we can determine whether and to what extent populism is linked to and more prevalent in certain policy fields, such as migration policy. Thus we ask:

RQ1: Is there a link between populist communication and the topic of the posting?

\section{Methods and Cases}

In comparing party communication in election campaigns in France, Germany and the UK, we opted for cases based on different political and media systems (within Western democracies), in order to focus on only one feature (populism in communication) that political parties may or may not have in common. The three countries differ considerably with regard to their political systems, having centralized (FR) or more federal (GER, UK) forms of governance, presidential (FR) or parliamentary (GER, UK) systems, and majoritiarian (UK, FR) or more consociational (GER) decision-making. Their media systems cover all three types identified by Hallin and Mancini (2004): polarized-pluralist (FR), democratic-corporatist (GER), and liberal (UK). In their updated and empirically richer categorization of media systems, Brüggemann et al. (2014) classify both the UK and Germany as central types, "characterized by strong public broadcasting, strict ownership regulation, and low press subsidies," (p. 1056) and France as the southern type, combining "the highest degree of political parallelism with the least professional journalism and the least inclusive press market." (p. 1056-1057) None of the three countries had populist parties in government position.

Facebook has become a major source of information and news. In all three countries approximately one third of internet users received their news through social media (France $36 \%$, Germany $31 \%$, and the UK 39\%), a large portion of which came from Facebook (Germany 
24\%, the UK 27\%, no data for France) (Reuters Digital News Report 2018: 10). Unlike Twitter, with its very short informational messages, postings on Facebook can be longer, more detailed, and do not force authors to be explicit and pointed. Since Facebook has become a standard platform for the campaign strategies of political actors (Author1, 2017), it is a prime source of official party communication. In the campaigns we analyze, all relevant political parties had Facebook profiles that they used for party communication.

Table 1: Number of postings for each country in time

$2014 \quad 2017 \quad 2018$

\begin{tabular}{llll}
\hline Germany & 421 & 546 & 215 \\
\hline United Kingdom & 586 & 686 & 273 \\
\hline France & 253 & 337 & 247 \\
\hline
\end{tabular}

A comparison of the three countries also produces longitudinal insight into different types of elections and election campaigns, and also provides a comparison with a randomly chosen nonelectoral period. All the countries participated in the (second-order) 2014 European Parliament elections and held (first-order) national parliamentary elections in 2017. The data we use originate from the political parties' official Facebook profiles and contain all postings published during the last two weeks of the electoral campaigns prior to the 2014 European Parliament and the 2017 national parliamentary elections, as well as during two weeks in January 2018 as a non-electoral period for comparison (data accessed via Sotrender). The data contain a total of 3564 postings from 24 political parties in Germany, the UK and France (Table 1). The data represent all major parties present during all three periods, except La République En Marche, La France Insoumise and Debout la France which did not exist in 2014 and no data are available for them in respect of the 2014 EP election. The list of parties and their characteristics are included in Appendix A.

We do recognize that often party leaders can be more relevant politically, reach a larger audience than their parties and can impact the likeability of messages (Bobba 2018). However, we focus on the party profiles only, for reasons of comparability and to avoid the intervention of personality traits, political status, celebrity status or biographical aspects. Engesser, Ernst, 
Esser \& Büchel's study (2017) on political leaders found that populism manifests in fragmented form on Facebook, and our study seeks to focus on the party side of this finding.

All postings were manually coded by three intensively trained coders (German and French native speakers, fluent in English). General inter-coder reliability between these coders was Krippendorff $\alpha=.762 .{ }^{1}$ A self-reliability test was run for each coder within a few weeks after the first coding, with the mean for the coders being Krippendorff $\alpha=.904$.

\section{Dependent variables}

Populism in communication is operationalized by using three distinct populism indexes for populism in content (PiC: PiC Empty, PiC Exclusionary, PiC Anti-elitist), following de Vreese et al. (2018); and by using one index for populism in style (PiS), following Bracciale and Martella (2017). There is less literature on populism in style than populism in content, and our operationalization also covers many variables that With et al (2019) suggest in their NCCR codebook on populism and in Wettstein et al's (2019) analysis of populist styles, such as emotionalization, common sense as a source and colloquial language.

PiC Empty contains references to the people. It is based on six possible characteristics of the posting: (1) referring to the people as the theoretical origin of power in a democracy, (2) praising the achievements of the people and emphasizing the virtues of the people, (3) demanding more power for the people or explicitly promoting the implementation of direct democracy, (4) presenting the party as the true and only representative of the people, (5) presenting other parties as non-representatives of the people, and (6) presenting the party as the defender of common sense and of the wisdom of regular people. PiC Empty contains six categories (2014 M=.130 $\mathrm{SD}=.39,2017 \mathrm{M}=.164 \mathrm{SD}=.45,2018 \mathrm{M}=.095 \mathrm{SD}=.35 ; \mathrm{DE} \mathrm{M}=.094 \mathrm{SD}=.67$, UK $\mathrm{M}=.235$ $\mathrm{SD}=.51, \mathrm{FR} \mathrm{M}=.019 \mathrm{SD}=.15$ ). The PiC Empty is a basic category (please see the theoretical categorization above) and is included in the two other categories.

PiC Exclusionary appeals to the people and proposes the exclusion of out-groups These postings: (1) invoke a monolithic people we the people vs. them), (2) name groups that the party does not see as part of society, (3) accuse other parties of ostracism (e.g. as fascists, populists, etc.), or (4) contain hostile and xenophobic language towards other groups. PiC Exclusionary contains ten elements $(2014 \mathrm{M}=.181 \mathrm{SD}=.52,2017 \mathrm{M}=.214 \mathrm{SD}=.563,2018 \mathrm{M}=.163 \mathrm{SD}=.50$; $\mathrm{DE} \mathrm{M}=.194 \mathrm{SD}=.56, \mathrm{UK} \mathrm{M}=.276 \mathrm{SD}=.62, \mathrm{FR} \mathrm{M}=.037 \mathrm{SD}=.23$ ).

\footnotetext{
${ }^{1}$ Calculated according to syntax by Andrew F. Hayes, http://www.afhayes.com
} 
PiC Anti-elitist appeals to the people and is measured by anti-elite claims: (1) attacking political elites (e.g. politicians, the government, other parties, the political class), (2) attacking economic elites (e.g. the banks, rich people, stock brokers), (3) attacking media elites (e.g. journalists, publishers, public service media), (4) attacking supranational elites (e.g. EU, UN, World Bank), (5) attacking legal elites (e.g. courts, supreme courts, lawyers, judges, law professors), (6) attacking other institutions (e.g. science/experts, the military, schools, the church, NGOs), and (7) attacking unspecified elites (e.g. the establishment, the state, the regimen, high society). PiC Anti-elitist contain thirteen features (2014 M=.184 SD=.53, 2017 $\mathrm{M}=.196 \mathrm{SD}=.52,2018 \mathrm{M}=.147 \mathrm{SD}=.45 ; \mathrm{DE} \mathrm{M}=.163 \mathrm{SD}=.51, \mathrm{UK} \mathrm{M}=.276 \mathrm{SD}=.60, \mathrm{FR} \mathrm{M}=.033$ $\mathrm{SD}=.19)$.

PiC Full Populism is a general category that combines all seventeen previous categories relating to empty populism, anti-elitism and the exclusion of out-groups. Although used throughout the article to facilitate some comparative description, it is not used in the regression analysis.

Populism in Style contains seven possible characteristics of the posting: (1) an appeal to emotion of fear, (2) the oversimplification of issues or solutions, (3) the use of non-precise language, with allusions, puns, and empty rhetoric, proverbs, stereotypes, clichés, and other expression of "popular wisdom," (4) the breaking of the rules of political correctness, (5) the use of vulgar language, and (6) the use of aggressive or provocative language (2014 M=.142 $\mathrm{SD}=.43,2017 \mathrm{M}=.216 \mathrm{SD}=.52,2018 \mathrm{M}=.185$ SD.53; DE $\mathrm{M}=.289 \mathrm{SD}=.60$, UK $\mathrm{M}=.190$ $\mathrm{SD}=.49, \mathrm{FR} \mathrm{M}=.021 \mathrm{SD}=.15)$.

Concerning policy fields, we coded each posting according to covering any specific topic (in case of multiple topics all topics were coded as present). Postings were coded according to twelve topics: economy, social issues, health, migration, education, foreign policy, Brexit (UK only), environment, security, transport, technology and media. In our sample, in 46\% (1661) of postings at least one of above topics were mentioned. Each posting was binary-coded for the presence or absence of the indexes' elements. This coding is non-exclusive as postings can contain more than one element within each index, for example a posting being anti-national, anti-government and anti-EU. The codebook is available as supplementary file Appendix B, including a summary sheet of all variables. 


\section{Independent variables}

To calculate variables indicating party characteristics, we use the Chapel Hill Expert Survey (CHES). The data from CHES 2014 and 2017 (and 2010 for BNP) are combined (mean scores or a score from one year if a party is studied only in one wave (e.g. LREM only in CHES 2017)).

Governmental vs. oppositional parties is a dummy variable with governmental (1) if a party was in government during the 2014-2018 period, even if only for a short while (e.g. LibDem in the UK).

Party family is a dummy variable coded separately for Radical Left (3 parties), Radical Right (5 parties), Center (6 parties), Left Leaning (3 parties), Right Leaning (3 parties), and Other (6 parties, e.g. Greens or regional parties).

Party size consists of three categories (coded as dummy per category): Major parliamentary (6), Minor Parliamentary (15), and Fringe (3). The status of each category is indicated after the most recent national election.

\section{Results}

Of the 3564 party postings on Facebook, 376 contained only populism in content, 317 contained only populism in style, and 213 simultaneously contained both forms of populism. In total, we identified populism in 906 postings, implying that populism is not a marginal phenomenon, but that it is present in about one fourth of all postings created by parties during the ten weeks under consideration.

Table 2: Regression analysis for Populism in Content and Populism in Style

\begin{tabular}{|c|c|c|c|c|}
\hline & PiC Empty & PiC Excluding & PiC Anti-elitism & PiS \\
\hline & IRR & IRR & IRR & IRR \\
\hline \multicolumn{5}{|c|}{ Time (Year 2014 ref.) } \\
\hline \multirow[t]{2}{*}{ Y2017 } & 1.170 & 1.251 & 1.079 & 1.702 \\
\hline & $(.7396,1.8502)$ & $(.8157,1.9184)$ & $(.7203,1.6167)$ & $(1.2224,2.3685)$ \\
\hline \multirow[t]{2}{*}{ Y2018 } & .806 & 1.015 & .874 & 1.434 \\
\hline & $(.4570,1.4221)$ & $(.6103,1.6869)$ & $(.5340,1.4306)$ & $(.9390,2.1901)$ \\
\hline \multicolumn{5}{|c|}{ Country (France ref.) } \\
\hline \multirow[t]{2}{*}{ Germany } & 5.956 & 5.260 & 5.834 & 12.013 \\
\hline & $(2.1878,16.2142)$ & $(2.6815,10.3197)$ & $(2.5000,13.6165)$ & $(5.5480,26.0110)$ \\
\hline \multirow[t]{2}{*}{ United Kingdom } & $15.844 \quad * * *$ & $7.753 \quad * * *$ & $11.981 \quad * * *$ & $10.003 \quad * * *$ \\
\hline & $(6.2927,39.8945)$ & $(4.0699,14.7687)$ & $(5.3291,26.9366)$ & $(4.5810,21.8405)$ \\
\hline \multicolumn{5}{|c|}{ Party Size (Major Parliamentary ref.) } \\
\hline \multirow[t]{2}{*}{$\begin{array}{l}\text { Minor } \\
\text { Parliamentary }\end{array}$} & .676 & 1.084 & .823 & .753 \\
\hline & $(.2797,1.6326)$ & $(.5524,2.1282)$ & $(.3572,1.8955)$ & $(.4191,1.3529)$ \\
\hline Fringe & .322 & 1.024 & .509 & .813 \\
\hline
\end{tabular}




\begin{tabular}{|c|c|c|c|c|}
\hline & $(.0920,1.1290)$ & $(.3728,2.8131)$ & $(.1728,1.4996)$ & $(.3240,2.0408)$ \\
\hline \multirow[t]{2}{*}{ Governmental } & .585 & .551 & .510 & 1.144 \\
\hline & $(.3327,1.0292)$ & $(.3442, .8804)$ & $(.2921, .8921)$ & $(.8139,1.6093)$ \\
\hline \multicolumn{5}{|c|}{ Party Ideological Family (Center, Regional and Green ref.) } \\
\hline \multirow[t]{2}{*}{ Radical Left } & 1.411 & .770 & 2.715 & 1.447 \\
\hline & $(.4409,4.5151)$ & $(.2916,2.0305)$ & $(1.0061,7.3259)$ & $(.5610,3.7302)$ \\
\hline \multirow[t]{2}{*}{ Radical Right } & 3.094 & 2.706 & 3.604 & 3.250 \\
\hline & $(1.3416,7.1350)$ & $(1.1865,6.1718)$ & $(1.7863,7.2722)$ & $(1.5844,6.6675)$ \\
\hline \multirow[t]{2}{*}{ Right } & 1.910 & 2.938 & 2.307 & 1.432 \\
\hline & $(.6922,5.2677)$ & $(1.2987,6.6482)$ & $(.8797,6.0492)$ & $(.5615,3.6502)$ \\
\hline \multirow[t]{2}{*}{ Left } & 1.190 & 1.824 & 1.331 & .888 \\
\hline & $(.4849,2.9223)$ & $(.9076,3.6664)$ & $(.5702,3.1055)$ & $(.4630,1.7021)$ \\
\hline \multirow[t]{2}{*}{ Constant } & $.016 \quad * * *$ & $.020 \quad * * *$ & $.020 \quad * * *$ & $.011 \quad * * *$ \\
\hline & $(.0035, .0764)$ & $(.0063, .0652)$ & $(.0051, .0798)$ & $(.0038, .0316)$ \\
\hline (1/df) Deviance & .4184 & .5177 & .4962 & .4700 \\
\hline (1/df) Pearson & 1.1809 & 1.2098 & 1.1216 & .9584 \\
\hline $\begin{array}{l}\text { Log } \\
\text { pseudolikelihood }\end{array}$ & $\begin{array}{l}- \\
1355.6418\end{array}$ & $\begin{array}{l}- \\
1713.9431\end{array}$ & $\begin{array}{l}- \\
1647.2335\end{array}$ & -1628.0842 \\
\hline
\end{tabular}

Note: GLM Negative binomial, IRR (Incidence Rate Ratios) are reported for easiness of interpretation, data was clustered by party*year. $* * * p<.001 * * p<.01 * p<.05 .95 \%$ Conf. Interval in the brackets

Table 2 presents the regression analysis on each form of populism discussed above. Notably, the regression analysis suggests that there is little variance over time in populism as communication. The exception is populism in style that was used almost twice as much during the 2017 national elections as in the 2014 EU elections. This suggests that populism in style may be used as a campaign strategy to mobilize voters in first-order elections. The variance between countries is also significant as political parties in both the UK and in Germany are more likely to employ populist communication in content and in style than parties in France. During all three periods there was a much lower level of populism prevalent in France than in the UK and Germany.

In respect of the influence of party characteristics and in contrast to what Inglehart and Norris (2016) suggested, we find that for party size there is no statistically significant difference when using populism as a communicative feature: minor and fringe parties use neither more nor less populism in the content and style of their postings than do major parliamentary parties. Thus we reject H1 (party size impacts on populism). We conclude that parties in government are less likely to use certain aspects of populism, especially exclusionary and anti-elitist populism. At the same time, there is not much difference between governmental and oppositional parties regarding empty populism and populism in style. This suggests that both types of parties refer to the people and employ typical stylistic elements on Facebook, such as over-simplification and overly informal language (A non-significant result, however, suggests that governmental 
parties may use it more than do non-governmental parties.). As a result, we partially confirm H2 (party position impacts on populism). Closer scrutiny of the political ideology of parties partially confirms the previous results. As expected and repeatedly shown in the literature, radical right-wing parties extensively employ populist communication in all its dimensions. They strongly advocate anti-elite messages and spearhead the use of populism in style. However, while radical right-wing parties are prone to use any kind of populism, they are joined by some traditional, moderate right-wing parties (the UMP in France and the Conservatives in the UK), who also use exclusionary populism. Both the radical left and radical right show a preference for strong anti-elite communication. Appendix $\mathrm{C}$ provides a table comparing the results and number of postings on the party level.

Graph 1. Relative mean for full populism and populism in style by party's ideology

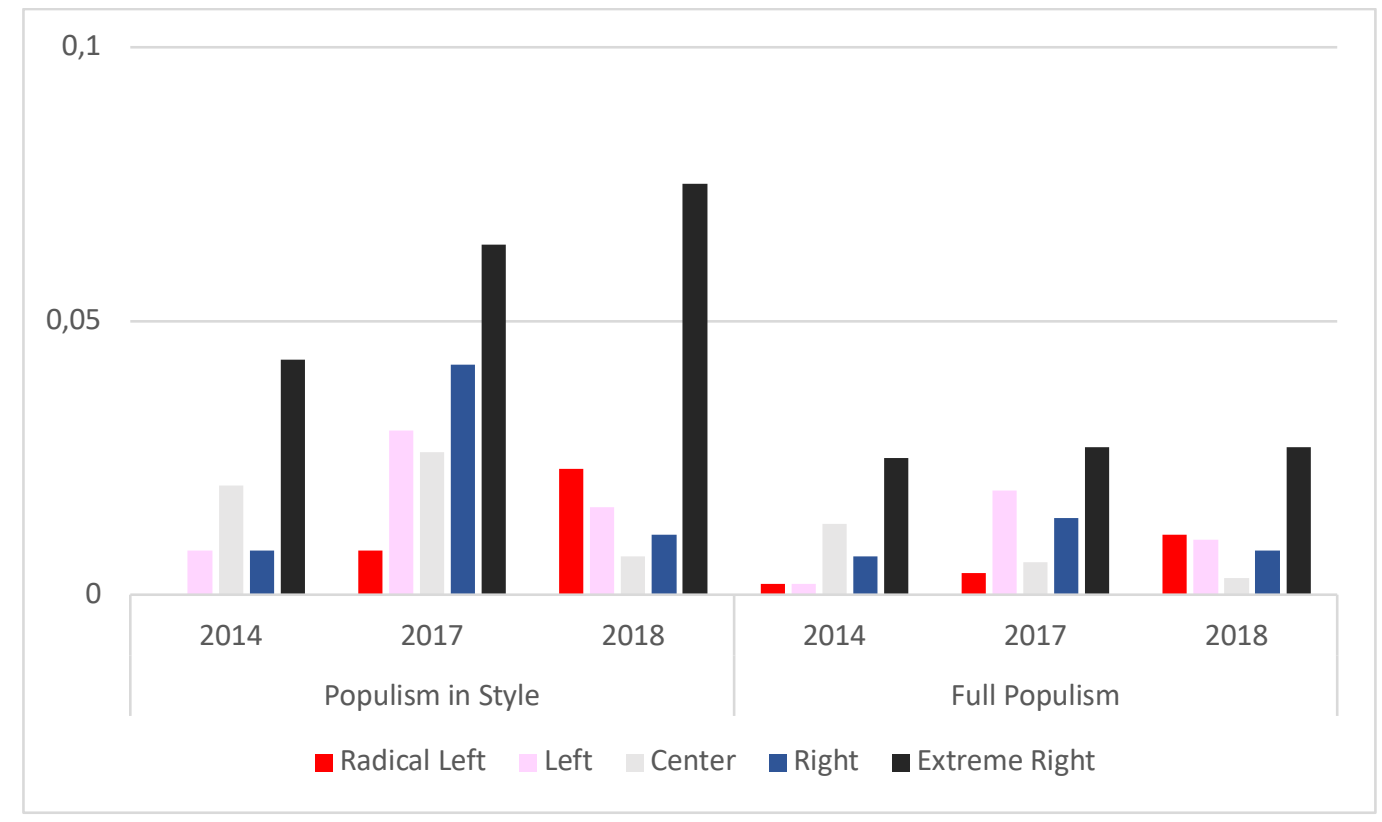

Anova analysis comparing populist communication according to party political ideology suggests a variation across the party spectrum regarding both populism in style $[\mathrm{F}(4,3559)=$ $41.45 \mathrm{p}=.000]$ and full populism (in content) $[\mathrm{F}(4,3559)=37.05 \mathrm{p}=.000]$. The post-hoc tests indicate strong dissimilarity not only for radical right-wing parties but also for all other parties. This confirms the previous results. We found a longitudinal variation for populism in style $[\mathrm{F}(2$, $3561)=7.96 \mathrm{p}=.000]$ (the post-hoc test indicates a stronger difference between 2014 and 2017), but not for full populism. The results (see Figure 1) suggest that across the political spectrum 
no party type is free from populist statements. The temporal development of populism in style and full populism by the radical parties is particularly notable. Since 2014, radical parties especially radical right-wing parties - have become more populist in their communication style, whether there was an election campaign or not. In fact, their style was most populist during the non-electoral period of 2018. Moreover, it is clear that radical right-wing parties pursue full populism: content that does not merely refer to a vague "people", but content that at the same time is anti-elitist and exclusionary of out-groups. This pattern remains stable over time and is independent of election campaigns. This differs from the moderate left-wing and right-wing parties who also mobilize support by using populist messages, but more so in national, firstorder elections, only to relax their emphasis on populism outside the election periods. Based on these results, we confirm H3 (party ideology impacts on populism). Indirectly, this finding also validates Inglehart and Norris' (2016) notion that cultural values matter.

Regarding longitudinal and cross-sectional variance, Figure 1 represents the prevalence of populism in the perspectives of both content and style. As in the regression analysis, the country differences are clearly visible. French parties are reluctant to use populism in content and populism in style, a trait most likely due to the difference between parties seen as populist (i.e. the Front National and France Insoumise) and all other parties. The descriptive data suggests that the former extensively uses populism in communication, whereas the latter seldom uses it. In contrast, all parties in the UK and Germany extensively use populist communication in their Facebook postings. Populism in style strongly increases over time in Germany, while empty populism or the mere invocation of the people dominates in the UK election campaigns, but clearly decreases during the non-electoral period. In France all forms of populism are at a much lower level than in the UK and Germany, but increased during the non-electoral period. 
Graph 2. Relative mean for populism in content and populism in style by year

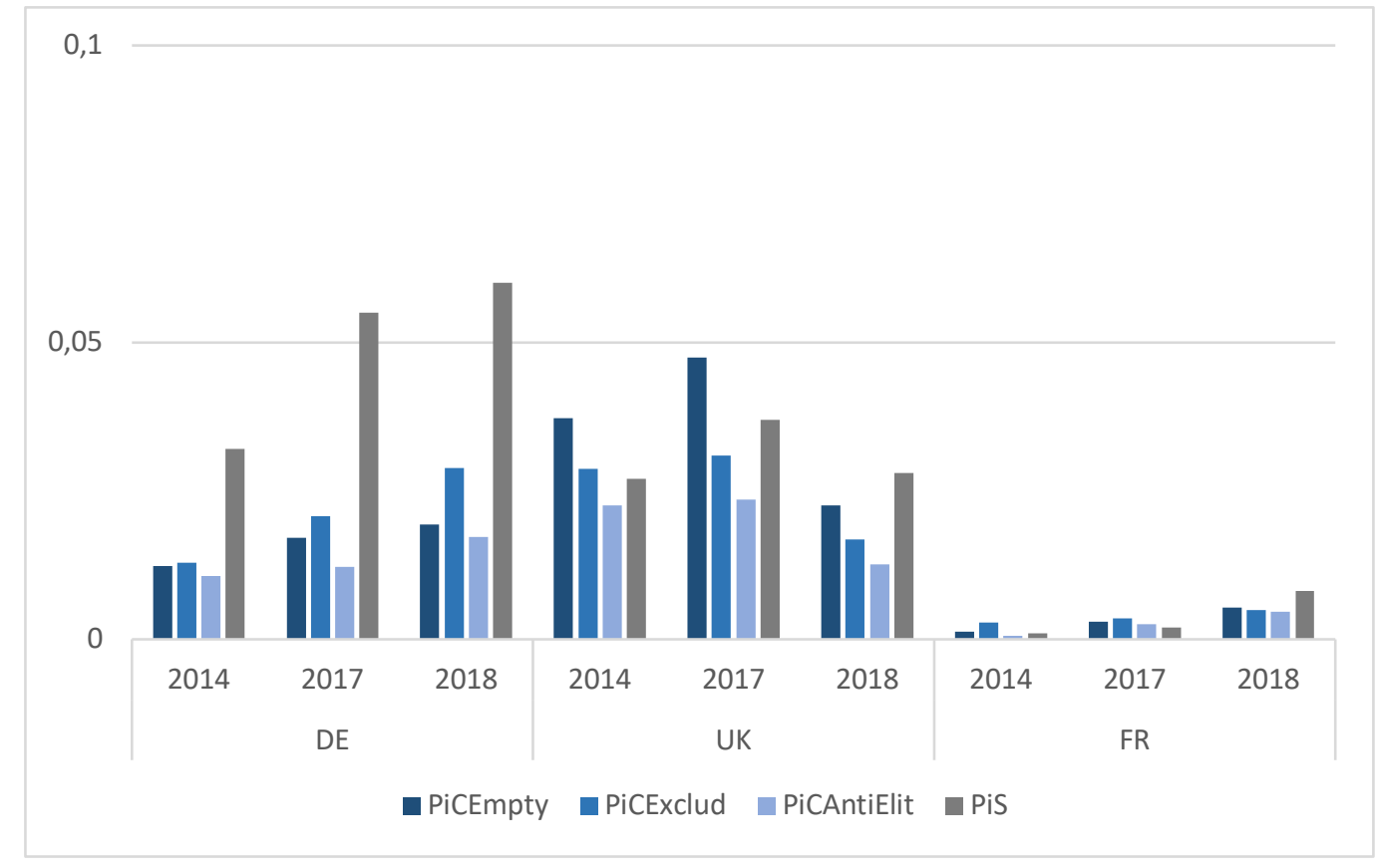

Note: To facilitate inter-index comparison, the mean score was averaged (by number of elements in each index).

Over time, exclusionary populism strongly increases in Germany and slightly increases in France, but not in the UK where it decreases during non-electoral periods. This confirms hypothesis, H4 (PiC and PiS increase over time) for Germany and France, but not for the UK where the levels of both PiC and PiS clearly peaked during first-order election campaigns (with empty populism dominating in 2014 and 2017 and PiS in 2018). We reject hypothesis H5 (PiC and PiS increase in all three countries), because it only holds true for France and Germany. H6 (PiC and PiS are more prevalent during first-order elections than during second-order elections and non-electoral periods) is confirmed for the UK, but not for Germany and France where all forms of populism increase over time, albeit on a higher level in Germany than in France.

Based on the data, we also respond to our research question (RQ1). The most prominent policy fields that parties posted about on Facebook were economic and social policy, but they were not particularly populist. Rather, we found that the perennial ("usual suspect") topics were the most populist, with postings on migration and security policy containing more than half of all the populist elements. 
Table 3. Policy fields and populism

\begin{tabular}{lcccc} 
& Populism & Full populism & PiS & N \\
\hline Migration policy & .60 & .48 & .47 & 172 \\
\hline Security policy & .50 & .32 & .37 & 119 \\
\hline Social policy & .40 & .28 & .20 & 259 \\
\hline Economic policy & .36 & .23 & .20 & 394 \\
\hline Health policy & .32 & .22 & .14 & 152 \\
\hline Foreign policy & .31 & .18 & .19 & 156 \\
\hline Education policy & .20 & .08 & .14 & 122 \\
\hline Environmental policy & .12 & .07 & .07 & 82 \\
\hline Brexit (the UK only) & .44 & .35 & .19 & 121
\end{tabular}

Populism indicates if any kind of populism (PiC or PiS) was evident in the posting. Numbers indicate the ratio of the posting containing populist communication or style to those which do not contain any populist element. Three topics (transport, technology, and media) did not receive any populist elements.

While not surprising, it is striking that about half the Facebook postings by political parties on migration policy contain full populism. These postings invoked the "people", and they contained anti-elitist notions as well as messages about the exclusion of out-groups, with the same number using a populist style. About one third of the postings on respectively security and social policy exhibited full populism. Education policy and environmental policy were the fields least related to full populism, although not completely free from populism either. Other categories that we controlled (e.g. technology, transportation, and media) did not contain any populist communication. Although only valid for the UK, postings about Brexit confirmed intuition and contained high levels of populism. Based on these findings, we conclude that PiC and PiS are more prevalent in specific policy fields. While populism is prevalent in Facebook messages of all the political parties across the political spectrum, it is evident that typical rightwing policy fields dominate the populist postings.

\section{Discussion and conclusion}

Our results underline that it makes sense to study populism as a communication phenomenon (rather than only as an actor type approach) that includes typical elements of content and elements of style. Populist elements were evident in the messages of all parties across the ideological spectrum, and confirm that over time a populist style is increasing particularly in 
the messages of radical parties on the left and right. But moderate and center parties are not always "non-populists", as they tend to use a populist style during first-order election campaigns, but less so during second-order campaigns and in non-electoral periods. As was expected from the literature review, radical right-wing parties employ all types of populism (full populism that contains elements of praising the people, being anti-elite, and excluding outgroups) on a constant level over time. Regarding the three countries included in our study, all forms and levels of populism, especially populism in style and exclusionary populism are increasing in Germany. In the UK, populist communication peaked during the 2017 national election, particularly empty populism, but not as much in 2014 and 2018. In France, all forms of populism are also increasing, but at a lower rate than in Germany and the UK. Considering that the radical-right Front National (renamed Rassemblement National) under Marine Le Pen, the radical left Melenchon movement La France Insoumise, and the newly founded movement La France En Marche under Emmanuel Macron participated in the 2017 elections, the very low level of populist messages in France is somewhat counter-intuitive. A closer scrutiny of the data reveals that En Marche, while occasionally referring to the people (empty populism), is the only case where no evidence of ostracism, the exclusion of out-groups, and the evoking of fear was found in their Facebook postings. This is remarkable in comparison to all the other parties. However, other French parties are also very reluctant to use populist communication. A possible explanation lies in the long tradition of legal constraints that prevent negative campaigning in France. Also, Front National is very centered on Marine Le Pen, a lot of communication in general and populistic in particular is emitted by the party leader, not by the party and thus not captured here.

Studying populism as a communication phenomenon allows for a differentiated view: Yes, populism is increasing and has been scoring at the ballot boxes. But in many cases, it consists only of empty references of "the people" by moderate parties in specific settings. This is hardly threatening the integrity of democratic elections. The more problematic elements, such as the exclusion of specific groups from society, xenophobia, homophobia, attacks on elites, institutions and intermediary actors of various kind can be obscured by a global focus on populism. In many cases, referring to "the people" is a cloak to mantle illiberal, anti-democratic or authoritarian notions as a presumable "popular" agenda.

An interesting finding is that populist style increased much stronger that populist content. This underlines the importance to see populism not only as an ideology or a political strategy, but as 
a particular form to communicate - employed by parties across the political spectrum. We can also interpret this a as sign for the brutalization of political language and public discourse.

Populism is also not limited to the perennial topics of migration and security, as we noted populist style elements in postings on environmental issues and on education, foreign and health policies. Environmental policy, in particular, could play an increasing role in the future since radical right-wing parties have recently turned to opposing the notion of a climate crisis and attack climate activists.

For a better understanding of how populism forms part of campaign strategies and how it mobilizes or demobilizes support, researchers need to look beyond only single type populist parties and their messages, speeches, party platforms, posters, and postings. Improved comparative research designs (beyond the particularities of individual parties or movements) and quantitative, data-based studies on more campaigns over longer time periods, can be attained by redirecting populism research from actor-centered approaches towards contentcentered approaches. The notable difference between the findings in respect of first-order and second-order elections and non-electoral periods suggests that, depending on the political situation, the prevalence and intensity of populism as communication varies. The contentcentered approach also makes better use of the available social media data of the past few years and allows new perspectives. Party communication is no longer limited to press releases and party manifestoes. It can be monitored by real-time research of social media, with the added advantage of generating much more data.

Our study, admittedly, has limitations. We only included one case of a second-order election, of first-order elections for each country, and one non-electoral period. Undoubtedly it would be worthwhile to continue and reproduce this study with data from the 2019 EU election and the next round of national parliamentary elections, including also party leaders. We only used data from the two weeks before the elections, covering the hot campaign phase. We only coded Facebook postings made by the parties, excluding comments of users and parties in response (although the parties were not very responsive and rarely contributed to the comment section). The inclusion of comments would show whether or not users are more populist than parties. Another way forward is a comparison across platforms, including Twitter and Instagram. Unfortunately, due to all restrictions on data from social media platforms, independent research is only "peeking through the keyhole" at the moment and only grasping in part what is happening on social media platforms during political campaigns. This situation poses a threat 
to democracy, especially since social media platforms have become a major source of news and information, also considering that populist messages across the political spectrum, time and location, undeniably form part of this environment.

\section{References}

Albertazzi, D., \& McDonnell, D. (2015). Populists in power. Routledge.

Blassnig, S., Engesser, S., Ernst, N., \& Esser, F. (2019). Hitting a nerve: Populist news articles lead to more frequent and more populist reader comments. Political Communication, 36(4), 629-651.

Bobba, G. (2018). Social media populism: Features and 'likeability' of Lega Nord communication on Facebook. European Political Science, 1-13.

Bracciale, R., \& Martella, A. (2017). Define the populist political communication style: the case of Italian political leaders on Twitter. Information, Communication \& Society, 20(9), 1310-1329.

Brüggemann, M., Engesser, S., Büchel, F., Humprecht, E., \& Castro, L. (2014). Hallin and Mancini revisited: Four empirical types of Western media systems. Journal of Communication, 64(6), 1037-1065.

Canovan, M. (1999). Trust the people! Populism and the two faces of democracy. Political Studies, 47(1), 2-16.

Casero-Ripollés, A., Sintes-Olivella, M. \& Franch, P. (2017). The populist political communication style in action: Podemos's issues and functions on Twitter during the 2016 Spanish general election. American Behavioural Scientist, 61(9), 986-1001.

De Vreese, C. H., Esser, F., Aalberg, T., Reinemann, C., \& Stanyer, J. (2018). Populism as an expression of political communication content and style: A new perspective. The International Journal of Press/Politics, 23(4), 423-438.

Engesser, S., Ernst, N., Esser, F., \& Büchel, F. (2017). Populism and social media: How politicians spread a fragmented ideology. Information, Communication \& Society, 20(8), 1109-1126.

Engesser, S., Fawzi, N., \& Larsson, A. O. (2017). Populist online communication: Introduction to the special issue. Information, Communication \& Society, 20(9), 1279-1292.

Ernst, N., Engesser, S., Büchel, F., Blassnig, S., \& Esser, F. (2017). Extreme parties and populism: an analysis of Facebook and Twitter across six countries. Information, Communication \& Society, 20(9), 1347-1364. 
Ernst, N., Esser, F., Blassnig, S., \& Engesser, S. (2019). Favorable opportunity structures for populist communication: Comparing different types of politicians and issues in social media, television and the press. The International Journal of Press/Politics, 24(2), $165-$ 188.

Hallin, D. C., \& Mancini, P. (2004). Comparing media systems: Three models of media and politics. Cambridge, England: Cambridge University Press.

Hameleers, M., Bos, L., \& de Vreese, C. H. (2017). "They did it”: The effects of emotionalized blame attribution in populist communication. Communication Research, 44(6), 870-900.

Hameleers, M., Bos, L., Fawzi, N., Reinemann, C., Andreadis, I., Corbu, N., ... \& Axelsson, S. (2018). Start spreading the news: A comparative experiment on the effects of populist communication on political engagement in sixteen European countries. The international journal of press/politics, 23(4), 517-538.

Hameleers, M., \& Schmuck, D. (2017). It's us against them: A comparative experiment on the effects of populist messages communicated via social media. Information, Communication \& Society, 20(9), 1425-1444.

Hameleers, M., \& Vliegenthart, R. (2020). The rise of a populist zeitgeist? A content analysis of populist media coverage in newspapers published between 1990 and 2017. Journalism Studies, 21(1), 19-36.

Hawkins, K. A., Riding, S., \& Mudde, C. (2012). Measuring populist attitudes. Committee on Concepts and Methods Working Paper Series. University of Georgia. BePress. https://works.bepress.com/cas_mudde/72/

Heiss, R., \& Matthes, J. (2017). Who 'likes' populists? Characteristics of adolescents following right-wing populist actors on Facebook. Information, Communication \& Society, 20(9), 1408-1424.

Inglehart, R. F., \& Norris, P. (2016). Trump, Brexit, and the rise of populism: Economic havenots and cultural backlash. Harvard Kennedy School Working Paper No. RWP16-026, https://papers.ssrn.com/sol3/papers.cfm?abstract_id=2818659.

Jacobs, K., \& Spierings, N. (2018). A populist paradise? Examining populists' Twitter adoption and use. Information, Communication \& Society, 1-16.

Jagers, J., \& Walgrave, S. (2007). Populism as political communication style: An empirical study of political parties' discourse in Belgium. European Journal of Political Research, 46(3), 319-345.

Klinger, U., \& Svensson, J. (2015). The emergence of network media logic in political communication: A theoretical approach. New Media \& Society, 17(8), 1241-1257. 
Koc-Michalska, K., Lilleker, D., Gibson, R., Michalski, T. \& Zajac, J. (2018). Populism and Facebook: 14 countries, 117 parties and the 2014 European Parliamentary election, http://eprints.bournemouth.ac.uk/30445/

Kreiss, D. (2016). Prototype politics: Technology-intensive campaigning and the data of democracy. Oxford University Press.

Laclau, E. (2005). On Populist Reason. London: Verso.

Manucci, L. \& Weber, E. (2017). Why the big picture matters: Political and media populism in Western Europe since the 1970s. Swiss Political Science Review, 23(3), 313-334.

Mazzoleni, G. (2008). Populism and the Media. In Twenty-first century populism (pp. 49-64). Palgrave Macmillan, London.

McGuigan, J. (1992). Cultural populism. London: Routledge.

Moffitt, B., \& Tormey, S. (2014). Rethinking populism: Politics, mediatisation and political style. Political Studies, 62(2), 381-397.

Mudde, C. (2004). The populist zeitgeist. Government and Opposition, 39(4), 541-563.

Neuner, F.G. \& Wratil, C. (2017). The myth of the ,boring election': populism and the 2017 German election. LSE European Politics and Policy (EUROPP) blog. http://eprints.1se.ac.uk/84827/

Oliver, J. E., \& Rahn, W. M. (2016). Rise of the Trumpenvolk: Populism in the 2016 Election. The ANNALS of the American Academy of Political and Social Science, 667(1), 189-206.

Pauwels, T. (2011). Measuring populism: A quantitative text analysis of party literature in Belgium. Journal of Elections, Public Opinion and Parties, 21(1), 97-119.

Poblete, M.E. (2015). How to assess populist discourse through three current approaches. Journal of Political Ideologies, 20(2), 201-218.

Reif, K., \& Schmitt, H. (1980). Nine second-order national elections-a conceptual framework for the analysis of European Election results. European Journal of Political Research, 8(1), 3-44.

Reuters Digital News Report (2018), Reuters Institute for the Study of Journalism, Oxford. http://media.digitalnewsreport.org/wp-content/uploads/2018/06/digital-news-report2018.pdf?x89475

Römmele, A., \& Gibson, R. (2020). Scientific and subversive: The two faces of the fourth era of political campaigning. New Media \& Society, 22(4), 595-610.

Rooduijn, M. (2014). The mesmerising message: The diffusion of populism in public debates in Western European media. Political Studies, 62(4), 726-744. 
Rovira Kaltwasser, C. (2018). Studying the (economic) consequences of populism. In $A E A$ Papers and Proceedings(Vol. 108, pp. 204-07).

Spierings, N., Jacobs, K., \& Linders, N. (2018). Keeping an Eye on the People: Who Has Access to MPs on Twitter? Social Science Computer Review, 0894439318763580.

Stanyer, J., Salgado, S., \& Strömbäck, J. (2016). Populist actors as communicators or political actors as populist communicators: Cross-national findings and perspectives. In Aalberg, T., Esser, F., Reinemann, C., Stromback, J., \& De Vreese, C. (Eds.) Populist political communication in Europe (pp. 363-374). Routledge.

Stier, S., Posch, L., Bleier, A., \& Strohmaier, M. (2017). When populists become popular: comparing Facebook use by the right-wing movement Pegida and German political parties. Information, Communication \& Society, 20(9), 1365-1388.

Taggart, P. (2000). Populism, Buckingham.

Tartar, A. (2017). How the Populist Right Is Redrawing the Map of Europe. Bloomberg, Dec 11, 2017. https://www.bloomberg.com/graphics/2017-europe-populist-right/

Treib, O. (2014). The voter says no, but nobody listens: causes and consequences of the Eurosceptic vote in the 2014 European elections. Journal of European Public Policy, 21(10), 1541-1554.

Van Kessel, S., \& Castelein, R. (2016). Shifting the blame. Populist politicians' use of Twitter as a tool of opposition. Journal of Contemporary European Research, 12(2).

Waisbord, S., \& Amado, A. (2017). Populist communication by digital means: presidential Twitter in Latin America. Information, Communication \& Society, 20(9), 1330-1346.

Wettstein, M., Esser, F., Büchel, F., Schemer, C., Wirz, D. S., Schulz, A., ... \& Wirth, W. (2019). What drives populist styles? Analyzing immigration and labor market news in 11 countries. Journalism \& Mass Communication Quarterly, 96(2), 516-536.

Wirth, W., Wettstein, M., Wirz, D. S., Ernst, N., Büchel, F., Schulz, A., .. Manucci, L. (2019, November). Codebook. NCCR Democracy Module II: The Appeal of Populist Ideas and Messages. https://doi.org/10.17605/OSF.IO/RYX42

Zulianello, M., Albertini, A., \& Ceccobelli, D. (2018). A populist zeitgeist? The communication strategies of Western and Latin American political leaders on Facebook. The International Journal of Press/Politics, 23(4), 439-457. 